\title{
First-year students' communication apprehension in learning French as foreign language
}

\author{
Dante Darmawangsa ${ }^{*}$, Vidi Sukmayadi ${ }^{2}$, and Azizul Halim Yahya ${ }^{3}$ \\ ${ }^{1}$ Department of French Language Education, Faculty of Language and Literature Education, Universitas \\ Pendidikan Indonesia, Jl. Dr. Setiabudhi No. 229, Bandung, West Java, Indonesia \\ ${ }^{2}$ Communications Department, Faculty of Social Science Education, Universitas Pendidikan Indonesia, Jl. Dr. \\ Setiabudhi No. 229, Bandung, West Java, Indonesia \\ ${ }^{3}$ Faculty of Communication and Media Studies, Universiti Teknologi Mara, UiTM Campus, 40450 Shah Alam, \\ Malaysia
}

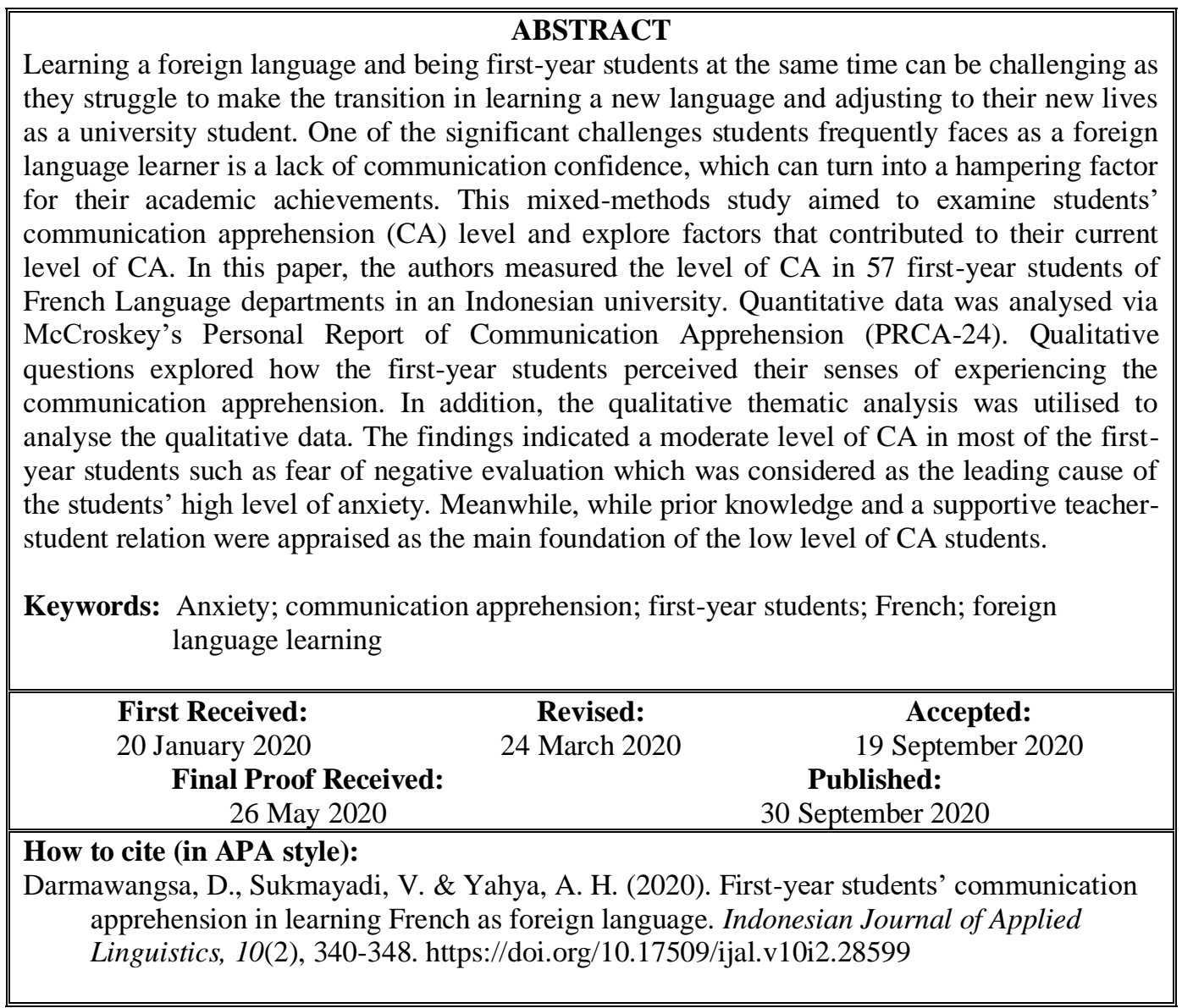

\section{INTRODUCTION}

As in any foreign language learning classroom, sometimes the most challenging students are the ones who are disengaged in the learning process. Since a classroom is a learning centre, educators as the learning providers have a responsibility to make sure that their students are back on track in the learning process. However, it is particularly tricky for reluctant students to fully engaged in the classroom (Min, 2016). As noted by Lucas (1984) students' communication disengagement in the classroom are triggered by such factors as unwillingness, nervousness, even fear, and this phenomenon is known as a case of communication apprehension.

Communication apprehension is widely known as one form of language anxieties along with fear of negative evaluation and fear of testing (Horwitz et al., 1986). Although the construction and concept of communication apprehension have emerged since

\footnotetext{
* Corresponding Author

Email: dante.darmawangsa@upi.edu
} 
1970 (see McCroskey, 1984), this phenomenon is still widely investigated in the past decade (e.g. Bragg, 2017; Mahdi, 2015; Matsuoka, 2008; Orbeta \& San Jose, 2013; Pribyl et al, 1998; Rosenfeld et al, 1995; Sham \& Azmi, 2018). In a foreign language classroom, the level of communication apprehension has more correlated to the students' level of proficiency of the target language or the students' linguistic background (Liu \& Jackson, 2008; Mahdi, 2015), rather than to the students' study duration (Molnar \& Crnjak, 2018).

French is one of the languages that has been spoken and studied throughout the globe. In 2018, there were 300 million French speakers worldwide (106 countries and territories). This fact sets French as the fifth most spoken world language, and it keeps growing ("La Francophonie en bref", n.d.). Additionally, the language has been spoken in a diverse language position, from spoken as a mother tongue, second language, official language, or even a foreign language.

Nevertheless, the teaching of a foreign language, no matter how popular the language is used, various challenges are always faced by both the teachers and the students' side. Regarding this, a study by Spetz (2018) on Swedish foreign language students indicated that the highest communication apprehension occurred on the beginner students; this phenomenon makes the work of a language teacher has become more challenging when it comes to working on the students' oral communicative competence. Another study from Aslim-Yetiş and Çapan (2013) has also shown anxiety that occurs during the speaking skill learning process; when the students are interviewed without having prepared for the task requested and not being able to be understood during their interaction.

There are four types of CA: (1) trait-like, which cuts across time, receiver, and situation; (2) context-based, which is associated with a single type of communication context cutting across receiver and time; (3) audience-based, which is associated with a single receiver or group of receivers cutting across context and time; and (4) situational, which is specific to a given context with a given receiver at a given time (McCroskey, 1984).

The French status in the Indonesian context is considered as one of the foreign languages that is formally studied from the secondary level of education to higher education. However, the acceptance of the language as a foreign language has its own challenges since there is no significant number of French learners or speakers. Comparing to other foreign languages such as English and Japanese, the language is not widely exposed and acknowledged. French language in Indonesian formal education institutions is offered at two levels of education: high school and college. For senior high school, out of a total of 27,205 schools (Kusnandar, 2019), only 200 schools are offering
French as school subjects (Hardini, 2019). Whereas for tertiary education, from a total of 4,670 higher educational institutions (see Ministry of Research, Technology and Higher Education, 2018), there are only six faculties and 20 vocational colleges (tourism, hospitality, culinary) that provide French language program (Hardini, 2019). Furthermore, in the non-formal education sector, there are only about 15,000 Indonesian students who study the French language in Institution courses such as Institut Français d'Indonésie (French Institute of Indonesia) and Alliance Française (French Alliance) (Hardini, 2019). The number is far less compared to 872.441 Japanese language learners and Mandarin with 1.046.490 students learning it (see Ichsan, 2015). This situation has resulted in French being a less popular foreign language to be learned in Indonesia.

The challenges in learning the language become more significant when the learning process has to deal with the learners' communication apprehension and the learners' preparedness as firstyear students. As described above, the majority of Indonesian university students who enrolled in French study programs did not attend the language program-based in high schools, or in other words, they do not have any prior knowledge in the French language.

This fact poses particular challenges for the students in a way that the students have to study a foreign language and at the same time have to adjust to their transition period between high school and university life.

The transition period of first-year students could be very challenging since it exposes students to the new various challenges, especially in academic matters. Angelo and Cross (1993, as cited in Naong et al, 2009) stated that some of the academic challenges, for example, are the first-year students require new skills and need to adopt a new style of learning. For the first-year students, the teaching and learning methods are different and more challenging than in high schools since they are responsible for their own learning and this is what will then affect their academic performance. More specifically, Fook and Sidhu (2015) further explained that first-year students mostly would face the following challenges: cognitive challenges, learning to become an active learner, coping with reading materials, instructional problem, time management, assignment burdens, and adjusting with cultural differences. Thus, the first-year phase becomes crucial for the students since this transition may affect the development of attitudes towards continuing learning (Hillman, 2005), since failure to successfully manage such transition may result in significant distress, poor academic performance (Yorke \& Longden, 2004, as cited in Hassel \& Ridout, 2018) as well as a cause of students' anxiety and distress (Lowe \& Cook, 2003) 
Due to the fact that the French language is not widely studied in Indonesia, and considering the challenges faced by first-year students, it is interesting to explore how the learners thrive in studying the language by measuring their communication apprehension toward language learning. Based on the rationale above, this paper attempts to measure and investigate the communication apprehension occurred in the firstyear Indonesian students who are studying French as a foreign language. This paper aims at exploring the phenomenon of communication apprehension in the classroom and why it happens. Thus, the authors formulate the following research questions: (1) what is the level of first-year students' communication apprehension in learning the French language? (2) What factors contribute to the students' level of communication apprehension?

\section{METHOD}

In the current study, the authors employed a mixed method of data collection to gain a deeper understanding of the research issues. As stated by Creswell (2013), a mixed-methods approach provides researchers with greater scope to investigate and a bigger chance to gain an in-depth understanding of the research problem. Hence, in measuring the communication apprehension, the authors collected the data quantitatively by distributing questionnaires that address questions concerning the students communication apprehension (CA) when communicating using a foreign language. Subsequently, in order to comprehend what factors contributed to their CA score, the authors also conducted interviews with the participants.

\section{Research site and respondents}

The study was conducted at the French Language department in an Indonesian public university. The study involved all of the first-year undergraduate students at that department. The research site was chosen since the department is acknowledged as one of the top tier institutions for studying a French language in the country (see "Directory of Study Program Accreditation Results", 2019) and the only
French Language Department who has been accredited by an international accreditation service (see "International Directory," n.d.). There are 57 students in total, and all students voluntarily participated in the study. Freshmen students are chosen as the participants so the data can be used as a basis for a further review and develop the learning process in the future.

In regard to the study ethical consideration, the authors refer the ethical research standards based on the research code of ethics developed by the Indonesian Institute of Sciences (2013). The interviews and visual data collection were carried out with all the required consents. During the interview process, the participants were informed of their rights as an informant and their anonymity were guaranteed. Every participant had the opportunity to sign an informed consent document to guarantee the protection and privacy of their information. Throughout the study and afterwards, the confidentiality identity of the respondents was guaranteed, and the interview recordings were obliterated.

\section{Quantitative data measurements}

The participants completed the interactional based data measurement developed by McCroskey (1984) known as Personal Report of Communication Apprehension-24 (PRCA-24). The PRCA-24 is the instrument which is most widely used to measure communication apprehension. It permits one to obtain sub-scores on the contexts of public speaking, dyadic interaction, small groups, and large groups. The instrument is composed of twenty-four statements concerning feelings about communicating with others, especially in using French as a medium of instruction.

PRCA-24 revealed a four-dimensional structure consisting roughly of the four contexts of the PRCA: group discussion (questions 1 to 6); meetings (questions 7 to 12); dyad/interpersonal (questions 13 to 18); and public speaking (questions 19 to 24 ) The survey result is calculated using CA sub-scores Scoring Formula and then total scores are converted into three levels of CA classification (High, Moderate, or Low level of CA). The norms used in the scoring formula is described in Table 1.

Table 1

Norms of Personal Report of Communication Apprehension-24 (PRCA-24)

\begin{tabular}{lcc}
\hline & Mean & Standard Deviation \\
\hline For Total Score & 65.6 & 15.3 \\
Group & 15.4 & 4.8 \\
Meeting & 16.4 & 4.8 \\
Dyad (Interpersonal) & 14.5 & 4.2 \\
Public & 19.3 & 5.1 \\
\hline
\end{tabular}

Qualitative data collection and analysis

In collecting the qualitative data, interviews were conducted at the convenience of each participant with minimal interference by the authors. The questions consist of semi-structured dialogue, openended questions, which provided some degree of freedom for the participant to describe the CA experience (Creswell, 2013; Patton, 2014). Each 
participant met with the authors twice, the first session was a focus group discussion and the second one was an individual interview session. Each session lasted between 45 and 60 minutes. The data collection stopped when the authors reach the data saturation or when there were no new themes or information emerged from the iterative interviews.

The data were analysed using interpretive qualitative analysis adapted from Miles and Hubermann (1994) steps of analysis consist of data reduction, data display, and verified conclusions. This analysis approach allowed the authors to investigate influential moments in participants' lives such as self-disclosure strategies and experiences pertaining to the topic of the study. The interviews result were transcribed. After that, the authors coded the transcript and categorised the codes into broader conceptual themes. These themes were then categorised and organised chronologically according to the order in which they emerged. Once the transcripts were coded and themes were identified, the frequency of the themes was examined across all of the transcripts to find out the influential factors for the students' CA scores.

\section{FINDINGS AND DISCUSSION}

Students' communication apprehension level

As mentioned in the method section, the authors employed the communication apprehension measurement based on McCroskey's (1984)
Personal Report of Communication Apprehension (PRCA-24). In terms of the scoring formula, the PRCA-24 has 24 self-reflected statements that are computed and converted the four communication contexts into scores. The four communication contexts, including group discussions, meetings, interpersonal conversations, and public speaking, are computed into sub-scores, and the total average of the score is considered as the overall communication apprehension (CA). Each of the communication contexts has its own scoring formula based on the PRCA-24 (see appendix) as described in Table 2.

In answering the first research question, the authors start by presenting the overall communication apprehension (CA) score and its interpretation. Then the sub-scores of each PRCA24 communication components are explained to portray which component that has a significant score toward the overall measurement. In interpreting the overall CA score, all of the four components subscores are added, and the scoring results are range between 24 and 120 with the following interpretation:

a) A high level of $\mathrm{CA}$ is indicated with the score between 83 and 120 .

b) A moderate level of CA is indicated with the score between 55 and 83 .

c) A low level of $\mathrm{CA}$ is indicated with the score between 24 and 55

Table 2

Scoring Formula for the PRCA-24 Sub-Scores

\begin{tabular}{ll}
\hline Group Discussion & Item 2 + Item 4 + Item 6 - Item 1 - Item 3 - Item 5 + 18 \\
Meetings & Item 8 + Item 9 + Item 12 - Item 7 - Item 10 - Item 11 + 18 \\
Interpersonal Conversations & Item 14 + Item 16 + Item 17 - Item 13 - Item 15 - Item 18 + 18 \\
Public Speaking & Item 19 + Item 21 + Item 23 - Item 20 - Item 22 - Item 24 + 18 \\
\hline
\end{tabular}

As a result, the overall CA measurement results in the first-year students' communication apprehension in learning French as a foreign language are described in the appendix.

The results for the students' communication apprehension level were based on 57 students (the total population) who completed the PRCA-24 questionnaires. The computation showed that $26 \%$ of the total students were categorised as high in CA level. Thirty-nine students or $68.4 \%$ of the participants were categorised with a moderate level of CA, and only $5.3 \%$ of the participants got a low level of communication apprehension.

Based on the PCRA-24 score, it can be seen that communication apprehension occurs as a challenge for the first-year students of the French department. Only three students have a low level of $\mathrm{CA}$ with the score range from 50 to 55 . The score can be interpreted that the students have less anxiety when they communicate in French than most of their classmates. However, with an average overall score of 73.2, the first-year students were considered to have a moderate level of $\mathrm{CA}$ when they learn French in the classroom. The data reflect that averagely the students' communication apprehension is still in a tolerable state. As stated by Lucas (2009), a level of human anxiety up to a tolerable point is not entirely a bad thing because the physiological arousal associated with anxiety can contribute to more considerable mental preparation, sharper physical awareness, and general readiness for future situation.

In terms of for four communication contexts of the PRCA-24 (group discussions, meetings, interpersonal conversations, and public speaking), scores on the four contexts can range from a low level (6) to a high level of CA (30), and any score above 18 indicates some degree of apprehension (Wrench et al., 2009). Subsequently, the average sub-scores of the first-year students are described in Table 3. 
Table 3

PRCA-24 Communication Context Score

\begin{tabular}{lc}
\hline PRCA-24 Communication Context & Average Score \\
\hline Group discussion & 16.0 \\
Meetings & 17.5 \\
Interpersonal Conversations & 18.5 \\
Public Speaking & 21.5 \\
\hline
\end{tabular}

The table 3 shows that public speaking and interpersonal conversation recorded as the highest average score of the students' communication apprehension. Based on the findings, it indicates that the biggest challenge for the students in learning French is to speak the language in front of the classroom and to have a conversation by using the language. In relations to foreign language learning, speaking skill has been considered as a significant factor in generating language learners' communication anxiety (De Saint Léger, 2009; Horwitz, 2010; Lucas, 1984). Since the first-year students are required to deliver their thoughts publicly far more often than in high schools, hence they are struggling in coping with their communication apprehension, particularly when they have to speak in a foreign language in front of others. This finding confirmed previous studies that found students encounter communication apprehension due to their limited speaking skill of the language, and thus they do not feel convenient to communicate in the foreign language in front of others (Amiri \& Puteh, 2018; Babapoor et al., 2018; Tsiplakides, 2009).

\section{The Students' Communication Apprehension Level}

Aside from examining the level of the first-year students' CA, another primary objective of this study was to explore the students' perspectives toward certain factors that contributed to their discomfort while communicating in the target language. After the authors obtained the computation data, follow-up interviews were conducted toward students who scored in the top and bottom tier to identify factors that cause their current level of CA. Subsequently, the authors found that the students were experiencing a high level of communication apprehension as a result of two main factors: 1) fear of their peers' negative evaluation, and 2) lack of the target language exposure. On the other hand, prior knowledge of the target language and proper classroom intervention were attributed to the students who have a low level of communication apprehension.

\section{Factors Contributed to High Level of CA}

In terms of having a high level of CA, the study showed that the students' communication apprehension was not caused by the fact that they did not realise the value of learning French, indolence, or lack of interest in the French language. The students' narratives provided a piece of strong evidence that they were hesitant to participate in classroom communication activities because they believed that they were not good at speaking. The students were also worried that their peers and teachers would evaluate them negatively. This hesitation can be seen in a statement from one of the highly anxious students:

"I like French, but I prefer not to take part in speaking because I am not confident with my French, I don't want to make mistakes cause I'm worried that my friends will laugh at me." (Interview Data R.56, 2019)

Another student also expresses her experience in avoiding mistakes in speaking the language:

"Since I don't know how to say it in French, it's better for me to stay quiet and say nothing rather than being exposed with the mistakes." (Interview Data R.43, 2019)

The statement highlights the respondent's social image concern and preoccupation with how the classmates would perceive the respondent. This type of concern often occurs in a situation where a student fears something, it is natural to avoid the fear or withdraw from it, and this is exactly what the apprehensive communication student does (Wrench et al., 2009).

Other high levels of CA respondents also believe that they always feel that they should produce error-free sentences when speaking in a foreign language and this pressure has become another source of their fear of negative evaluation This finding appears in unison with the study by Gregersen (2003) and Aeni et al. (2017) who concluded that anxious foreign language learners tend to focus on form rather than the central point of the message.

The second factor that experienced by the apprehensive communication student is the lack of language exposure. Another student with a high level of $\mathrm{CA}$ describes her insights on the lack of language exposure:

"Unlike English or Japanese, I need to work extra hard to get the language exposure in learning French; not many people learn the language and not many movies or other kinds of literature. So there is less opportunity to enhance the productive language skill." (Interview Data R.54, 2019)

It can be seen from the response that since Indonesia is not a francophone country, the opportunity to get the language exposure is limited. As recommended by (Yin, 2015), foreign language 
learners should be continually exposed to the target language through various types of media to motivate and improve their language proficiency. Hence, this fact opens a gap that needs to be narrowed by the French language teachers by providing access and encouraging the students to get higher exposure to the language on a daily basis.

\section{Factors Contributed to Low Level of CA}

Students with a low level of CA tends to have low general anxiety, tolerates ambiguous situations, has a high degree of self-control, is adventurous, emotionally mature, extroverted, has high selfesteem, innovative, and can tolerate relatively high levels of disagreement (Wrench et al., 2009). In this study, the PRCA-24 result showed that only $5.3 \%$ of the total students have a low level of communication apprehension. In that case, it is interesting to see why those students have a peculiar level of $\mathrm{CA}$ comparing to other students.

Based on the interviews conducted with a low CA level students, they admitted that their prior knowledge and exposure of the target language have a significant contribution to their current level of communication apprehension. As a student commented:

"I had learned languages other than English when I was in high school, so I still remember how to use the language, and I think it also helps me manage my strategy in studying French right now" (Interview Data R.36, 2019)

In addition, all the students who have a low level of CA had experience in studying the language previously. The responses indicate that since the students already learned the language, it eases the anxiety of communicating in the classroom because the students already know the necessary expression to communicate in the target language.

Another finding of this study also indicated that classroom intervention in the form of setting up a supporting system community and establishing a supportive teacher-student relation and classroom atmosphere. This kind of support that focus on classroom activities help students improve their verbal communication (Interview Data R.23 \& R.53, 2019).

As an illustration of the support system, the French Department in this study has been establishing a support group consist of senior and first-year students. This type of learning community can provide an ideal environment for "optimal motivation" (Alderman, 2004), and a "collaborative atmosphere" that can assist the students in reducing their fear of language mistakes (Gregersen, 2003).

These findings can provide a basis for further evaluation for the curriculum development, especially for the French Language Department at the research site. The department policymakers could establish a strategy to narrow the gap in a way that a program can be designed to encourage as well as support those who have no prior knowledge of the language to thrive in the learning process with less anxiety. Establishing a language learning by relieving unnecessary anxiety means to create more effective language learning and to instil students' interest and motivation to learn a foreign language (Young, 1991).

\section{CONCLUSION}

In summary, communication apprehension (CA) or anxiety can be experienced by anyone, including first-year students. Therefore, the authors argue that it is essential that a learning center provides positive supports from students as well as creating an environment where students also engage in positive behaviours such as learning how to construct constructive, rather than negative criticisms.

Based on the findings, it can be concluded that most of the first-year students of French Department have a moderate level of $\mathrm{CA}$ in which fear of negative evaluation becomes the primary source of the students' anxiety. On the contrary, prior knowledge and an establishment of supportive teacher-student relations were appraised as the main contributing factors for the students who have a low level of CA.

The findings of the study can serve as an additional insight into the development of coping strategies toward language anxiety, particularly students' communication apprehensions in the language classroom setting. This study can also contribute to the development of what?? language teaching-learning. Hence, in order to have more implication to the knowledge, the authors would like to recommend investigating the first-year students' communication apprehension in a broader geographical scope to recognise the current level of communication apprehension of foreign language learners in the country and how they will strive from it.

\section{ACKNOWLEDGEMENT}

We would like to thank all parties, including the participants who willingly participated in this research, and in particular, those who made a significant contribution to the writing and / or improvement of the manuscript.

\section{REFERENCES}

Aeni, N., Jabu, B., Rahman, M. A., \& Strid, J. E. (2017). English oral communication apprehension in students of Indonesian maritime. International Journal of English Linguistics, 7(4), 158-165. https://doi.org/10.5539/ijel.v7n4p158

Alderman, M. K. (2004). Motivation for achievement: Possibilities for teaching and 
learning ( $2^{\text {nd }}$ ed). Lawrence Erlbaum

Associates Publishers.

Amiri, F., \& Puteh, M. (2018). Oral communication apprehension among international doctoral students. English Language Teaching, 11(2), 164-171. https://doi.org/10.5539/elt.v11n2p164

Aslim-Yetiş, V., \& Çapan, S. (2013). L'anxiété langagière chez des étudiants turcs apprenant le Français. The Journal of International Social Research, 6(24), 14-26.

Babapoor, M., Seifoori, Z., \& Chehreh, M. (2018). Intermediate EFL learners' shyness, communication apprehension, and the accuracy/fluency of their oral performance. In Research in English Language Pedagogy, 6(2), 205-222. http://relp.khuisf.ac.ir/article_542580_836365 31aaa5c4777d882925a606fdc4.pdf

Bragg, J. R. (2017). Communication apprehension among community college students: A phenomenology [Doctoral Dissertation, East Tennessee State University]. East Tennessee State University Electronic Theses and Dissertations Database.

Creswell, J. W. (2013). Research design: Qualitative, quantitative, and mixed methods approaches $\left(4^{\text {th }}\right.$ ed.). SAGE Publications, Inc.

De Saint Léger, D. (2009). Self-Assessment of speaking skills and participation in a foreign language class. Foreign Language Annals, 42(1), 158-178.

https://doi.org/10.1111/j.19449720.2009.01013.x

Directory of Study Program Accreditation Results (2019). National Accreditation Board for Higher Education. https://www.banpt.or.id/direktori/prodi/pencar ian_prodi.php

Fook, C. Y., \& Sidhu, G. K. (2015). Investigating learning challenges faced by students in higher education. Procedia - Social and Behavioral Sciences, 186(May 2016), 604612. https://doi.org/10.1016/j.sbspro.2015.04.001

Gregersen, T. S. (2003). To err is human : A reminder to teachers of language-anxious students. Foreign Language Annals, 36(1), 25-32. https://doi.org/10.1111/j.19449720.2003.tb01929.x

Hardini, T.I. (2019, September-October). Une langue romantique et sexy. Le français dans le monde, 425, 28. https://www.franceeducationinternational.fr/sites/default/files/atoms/files/a rticle-fdlm-10-ans-delf-prim.pdf

Hassel, S., \& Ridout, N. (2018). An investigation of first-year students' and lecturers' expectations of university education. Frontiers in psychology, 8, 2218. https://doi.org/10.3389/fpsyg.2017.02218

Hillman, K. (2005). The first year experience: The transition from secondary school to university and TAFE in Australia.

https://research.acer.edu.au/cgi/viewcontent.c gi? article $=1043 \&$ context=lsay_research

Horwitz, E.K., Horwitz, M. B., \& Cope, J. (1986). Foreign language classroom anxiety. The Modern Language Journal, 70(2), 125-132. https://doi.org/10.5840/ajs2012281-29

Horwitz, E.K. (2010). Foreign and second language anxiety. Language Teaching, 43(2), 154-167. https://doi.org/10.1017/S026144480999036X

Indonesian Institute of Sciences. (2013, July 25). Ethics in research. http://pusbindiklat.lipi.go.id/wpcontent/uploads/Perka-LIPI-tentang-KodeEtika-

Peneliti.pdf\#: :text=Kode\%20Etika\%20Peneli ti\%20adalah\%20acuan,kepada\%20Tuhan\%20 Yang\%20Maha\%20Esa

International Directory, (n.d.). Accreditation Service for International Schools, Colleges and Universities.

https://www.asicuk.com/internationaldirectory/

Ichsan, S.A. (2015, October 27). RI pembelajar bahasa Jepang terbanyak kedua. Republika. https://www.republika.co.id/berita/koran/dida ktika/15/10/27/nwva475-ri-pembelajarbahasa-jepang-terbanyak-kedua

Kusnandar, B.V. (2019, June 24). Berapa jumlah SMA dan SMK di Indonesia? https://databoks.katadata.co.id/datapublish/20 19/06/24/berapa-jumlah-sma-dan-smk-diindonesia

La Francophonie en bref. (n.d.). Organisation internationale de la

francophonie. https://www.francophonie.org/l a-francophonie-en-bref-754

Liu, M., \& Jackson, J. (2008). An exploration of Chinese EFL learners' unwillingness to communicate and foreign language anxiety. The Modern Language Journal, 92(1), 71-86.

Lowe, H., \& Cook, A. (2003). Mind the gap: Are students prepared for higher education? Journal of Further and Higher Education, 27(1), 53-76. https://doi.org/10.1080/03098770305629

Lucas, J. (1984). Communication apprehension in the ESL classroom: Getting our students to talk. Foreign Language Annals, 17(6), 593598. https://doi.org/10.1111/j.19449720.1984.tb01748.x

Lucas, S. E. (2009). The art of public speaking $\left(10^{\text {th }}\right.$ ed.). McGraw-Hill.

Mahdi, D. A. (2015). Relationship between oral communication apprehension and communication competence among EFL students. King Khalid University Journal of 
Humanities, 24(3), 289-306.

Matsuoka, R. (2008). Communication apprehension among Japanese college students. Pan-Pacific Association of Applied Linguistics, 12(2), 3748.

McCroskey, J. C. (1984). The communication apprehension perspective. In J. A. Daly \& J. C. McCroskey (Eds.), Avoiding communication: Shyness, reticence, and communication (pp. 13-38). SAGE Publications.

Miles, M. B., \& Huberman, A. M. (1994). Qualitative data analysis: An expanded sourcebook. SAGE.

Min, H. (2016). A study on silence phenomenon in college English classroom. International Journal of Education and Research, 4(6), 451-458. www.ijern.com

Ministry of Research, Technology and Higher Education. (2018). Higher education statistical year book. Pusdatin Iptek Dikti.

Molnar, D., \& Crnjak, G. (2018). Exploring foreign language communication apprehension among the English language university students in the English language classroom setting. European Journal of Social Science Education and Research, 5(2), 27-39. https://doi.org/10.26417/ejser.v5i2.p27-39

Naong, M. N., Zwane, M. G., Mogashoa, L. G., \& Fleischmann, E. (2009). Challenges of teaching first-year students at institutions of higher learning. International Education Studies, 2(2), 170-179. https://doi.org/10.5539/ies.v2n2p170

Orbeta, E. D., \& San Jose, A. E. (2013). Apprehension in language learning anxiety as significant correlate of oral performance in English of college freshmen. International Journal of Multidisciplinary Research, 5(1), 155-164. https://doi.org/10.7718/iamure.v5i1.622

Patton, M. Q. (2014). Qualitative research \& evaluation methods: Integrating theory and practice. SAGE Publications.

Pribyl, C. B., Keaten, J. A., Sakamoto, M., \& Koshikawa, F. (1998). Assessing the crosscultural content validity of the Personal Report of Communication Apprehension scale (PRCA-24). Japanese Psychological Research, 40(1), 47-53. https://doi.org/10.1111/1468-5884.00074

Rosenfeld, L. B., Grant III, C. H., \& McCroskey, J. C. (1995). Communication apprehension and self-perceived communication competence of academically gifted students. Communication Education, 44, 79-86.

Sham, R. M., \& Azmi, M. N. L. (2018). Causal relationship between oral performance and communication apprehension. KnE Social Sciences, 3(4), 769-783. https://doi.org/10.18502/kss.v3i4.1984

Spetz, H. (2018). L'anxiété langagière et la production orale Une étude sur les étudiants suédois de Français langue étrangère à l'université. http://www.divaportal.org/smash/get/diva2:1222877/FULLTE XT01.pdf

Tsiplakides, I. (2009). Helping students overcome foreign language speaking anxiety in the English Classroom: Theoretical issues and practical recommendations. International Education Studies, 2(4), 39-44. https://files.eric.ed.gov/fulltext/EJ1065743.pdf

Wrench, J. S., Richmond, V. P., \& Gorham, J. (2009). Communication, affect, \& learning in the classroom ( $3^{\text {rd }}$ ed.). Tappestry Press.

Yin, M. (2015). The Effect and Importance of Authentic Language Exposure in Improving Listening Comprehension [Master Thesis]. St. Cloud State University Database.

Young, D. J. (1991). Creating a low-anxiety classroom environment: What does language anxiety research suggest? The Modern Language Journal, 75(4), 426-437. https://doi.org/10.1111/j.15404781.1991.tb05378.x 
$\underline{\text { Appendix }}$

Overall PRCA-24 Results

\begin{tabular}{|c|c|c|c|c|c|}
\hline \multirow{2}{*}{ Respondents } & \multicolumn{4}{|c|}{ PRCA Components } & \multirow[b]{2}{*}{ Score } \\
\hline & $\begin{array}{c}\text { Group } \\
\text { Discussion }\end{array}$ & Meetings & $\begin{array}{l}\text { Interpersonal } \\
\text { Conversations }\end{array}$ & $\begin{array}{c}\text { Public } \\
\text { Speaking }\end{array}$ & \\
\hline $\mathbf{1}$ & 19 & 24 & 22 & 25 & 90 \\
\hline 2 & 15 & 18 & 21 & 16 & 70 \\
\hline 3 & 18 & 20 & 21 & 24 & 83 \\
\hline 4 & 17 & 17 & 17 & 14 & 65 \\
\hline 5 & 17 & 18 & 20 & 25 & 80 \\
\hline 6 & 17 & 18 & 17 & 22 & 74 \\
\hline 7 & 15 & 17 & 17 & 20 & 69 \\
\hline 8 & 14 & 14 & 17 & 20 & 65 \\
\hline 9 & 19 & 14 & 20 & 23 & 76 \\
\hline 10 & 15 & 15 & 15 & 20 & 65 \\
\hline 11 & 16 & 14 & 15 & 15 & 60 \\
\hline 12 & 15 & 16 & 18 & 20 & 69 \\
\hline 13 & 15 & 17 & 16 & 17 & 65 \\
\hline 14 & 17 & 12 & 17 & 16 & 62 \\
\hline 15 & 14 & 14 & 16 & 17 & 61 \\
\hline 16 & 17 & 12 & 15 & 16 & 60 \\
\hline 17 & 14 & 15 & 16 & 18 & 63 \\
\hline 18 & 16 & 17 & 18 & 18 & 69 \\
\hline 19 & 18 & 14 & 15 & 22 & 69 \\
\hline 20 & 14 & 18 & 17 & 19 & 68 \\
\hline 21 & 16 & 22 & 21 & 21 & 80 \\
\hline 22 & 19 & 22 & 22 & 24 & 87 \\
\hline 23 & 14 & 14 & 12 & 13 & 53 \\
\hline 24 & 14 & 18 & 15 & 25 & 72 \\
\hline 25 & 15 & 12 & 10 & 13 & 50 \\
\hline 26 & 18 & 22 & 19 & 20 & 79 \\
\hline 27 & 15 & 14 & 15 & 15 & 59 \\
\hline 28 & 17 & 16 & 15 & 17 & 65 \\
\hline 29 & 18 & 19 & 17 & 19 & 73 \\
\hline 30 & 18 & 19 & 19 & 24 & 80 \\
\hline 31 & 17 & 16 & 17 & 22 & 72 \\
\hline 32 & 22 & 21 & 18 & 16 & 77 \\
\hline 33 & 16 & 20 & 19 & 25 & 80 \\
\hline 34 & 17 & 9 & 17 & 15 & 58 \\
\hline 35 & 12 & 13 & 21 & 22 & 68 \\
\hline 36 & 11 & 9 & 10 & 13 & 43 \\
\hline 37 & 18 & 21 & 22 & 28 & 89 \\
\hline 38 & 18 & 19 & 23 & 25 & 85 \\
\hline 39 & 16 & 18 & 20 & 21 & 75 \\
\hline 40 & 16 & 15 & 16 & 18 & 65 \\
\hline 41 & 18 & 18 & 21 & 23 & 80 \\
\hline 42 & 19 & 23 & 23 & 24 & 89 \\
\hline 43 & 21 & 24 & 25 & 26 & 96 \\
\hline 44 & 15 & 19 & 17 & 24 & 75 \\
\hline 45 & 17 & 16 & 18 & 17 & 68 \\
\hline 46 & 18 & 20 & 21 & 26 & 85 \\
\hline 47 & 16 & 19 & 23 & 24 & 82 \\
\hline 48 & 14 & 20 & 20 & 24 & 78 \\
\hline 49 & 19 & 21 & 20 & 23 & 83 \\
\hline 50 & 21 & 22 & 21 & 22 & 86 \\
\hline 51 & 20 & 24 & 21 & 24 & 89 \\
\hline 52 & 17 & 14 & 13 & 16 & 60 \\
\hline 53 & 12 & 12 & 11 & 17 & 52 \\
\hline 54 & 26 & 27 & 30 & 25 & 108 \\
\hline 55 & 14 & 15 & 16 & 22 & 67 \\
\hline 56 & 22 & 23 & 24 & 24 & 93 \\
\hline 57 & 20 & 19 & 24 & 26 & 89 \\
\hline & & erage Score & & & 73.2 \\
\hline
\end{tabular}

